\title{
Determination of the Variations on Battery Consumption According to Temperature and Relative Humidity of Silicon Labs Si7021Wireless Sensor Systems in Greenhouse
}

\author{
Serada Silicon Labs Si7021 Kablosuz Sensör Sistemlerinin \\ Sıcaklık ve Neme Göre Pil Tüketimindeki Değișimlerinin \\ Belirlenmesi
}

\begin{abstract}
Celil Serhan Tezcan ${ }^{1}$, Kemal Sulhi Gündoğdu ${ }^{2 *}$
Geliş / Received: 15/02/2021

Revize / Revised: 22/05/2021

Kabul / Accepted: 22/05/2021

ABSTRACT

Climatic parameters need to be measured and necessary arrangements should be made according to these observations in order to be suitable for greenhouse climatic conditions in agricultural production. In agricultural production, it is important to know the temporal change of climatic values belonging to different locations of the greenhouse in order to ensure the comfort of plant growing environment. Today, the use of sensors determining various climatic parameters is becoming widespread. The design of the sensor system to include battery and wireless communication technology makes it easier to position the sensor in the desired position in the greenhouse. In this study, it was tried to determine the daily battery consumption of Silicon Labs Si7021 sensors used to determine temperature and humidity values in a greenhouse according to temperature and humidity values. In this study, 18 sensors were used and placed in different locations in the greenhouse. Temperature, relative humidity and sensor battery voltage measurements were carried out for twelve months between 2016-2017 in five minute intervals. From these values, daily average temperature, relative humidity and battery voltage changes were determined. Data were tested by ANOVA, regression and correlation analyzes. According to the results, it was investigated whether there was a significant relationship between the daily battery level change in the sensors used and the daily average temperature and humidity values. It is concluded that there is no strong relationship to create regression model between daily battery voltage change and two environmental parameters for all sensors.
\end{abstract}

Keywords- Temperature, Relative Humidity, Silicon Labs Si7021 Wireless Sensor, Battery Consumption, Greenhouse

\section{öZ}

Tarımsal üretimde sera iklim şartlarına uygun olması için iklimsel parametrelerin ölçülmesi ve bu gözlemlere göre gerekli düzenlemelerin yapılması gerekmektedir. Tarımsal üretimde, bitki yetiştirme ortamının konforunu sağlamak için seranın farklı yerlerine ait iklim değerlerinin zamansal değiş̧imini bilmek önemlidir. Günümüzde çeşitli iklim parametrelerini belirleyen sensörlerin kullanımı yaygınlaşmaktadır. Sensör sisteminin pil ve kablosuz iletişim teknolojisini içerecek şekilde tasarlanması, sensörün serada istenilen konuma konumlandırılmasını

1İletişim: cstezcan@gmail.com (https://orcid.org/0000-0002-3423-9402)

Geomatik Mühendisliği Bölümü, İstanbul Teknik Üniversitesi, Ayazağa Kampüsü 34469-İstanbul

2*Sorumlu yazar iletișim: kemalg@uludag.edu.tr (https://orcid.org/0000-0002-5591-4788)

Biyosistem Mühendisliği Bölümü, Bursa Uludağ Üniversitesi, Görükle Kampüsü 16059-Bursa 
kolaylaştııır. Bu çalışmada, bir serada sıcaklık ve nem değerlerinin belirlenmesinde kullanılan Silicon Labs Si7021 sensörlerinin günlük pil tüketiminin sıcaklık ve nem değerlerine göre belirlenmesi amaçlanmıştır. Bu çalışmada 18 adet sensor kullanılmış ve serada farklı yerlere yerleștirilmiștir. 2016-2017 yılları arasında on iki ay boyunca beş dakikalık aralıklarla sıcaklık, bağıl nem ve sensor pil voltajı ölçümleri yapılmıştır. Bu değerlerden günlük ortalama sıcaklık, bağıl nem ve akü voltaj değişimi belirlenmiștir. Veriler ANOVA, regresyon ve korelasyon analizleri ile test edildi. İstatistiksel analiz sonuçlarına göre, kullanılan sensörlerde günlük pil seviyesi değişimi ile günlük ortalama sıcaklık ve nem değerleri arasında anlamlı bir ilişki olup olmadığı araştırılmıştır. Tüm sensörler için günlük pil voltajı değişimi ile iki çevresel parametere arasında regresyon modeli oluşturmak için güçlü bir ilişki olmadığı sonucuna varılmıştır.

\section{AnahtarKelimeler-Sicaklık, Bağıl Nem, Silion Labs Si7021 Kablosuz, Sensörü, Pil Tüketimi, Sera}

\section{INTRODUCTION}

Due to use of open-source sensor systems, price advantage, easy installation and usage, flexibility that wireless deployment provide sit has become widespread in different sectors in recent years. A sensor network enables information to be easily accessed anytime and anywhere. It performs this function by collecting, processing, analyzing, and spreading data. Thus, the network plays an active role in creating an intelligent environment [1].

Wireless connection is a flexible communication system that transmits data over the air by electromagnetic waves to minimize problems caused by wired communication difficulties in the area to be used. Despite the constraints such as physical dependence in the use of wired systems, the need for energy and the size of the physical dimensions of the hardware structures, practical, cost-effective, and efficient systems can be implemented with wireless sensor network technology [2].

Wireless Sensor Networks are created by randomly placing many short-range, low-capacity transmitters, low-cost and powerful sensors in environments that are not easily accessible and unreliable. In the sensor networks, the data perceived from the physical environment with various sensors are transmitted wirelessly to the information processing network with the targets by connection with each other. A sensor node is a node in a sensor network that is capable of performing some processing, gathering sensory information and communicating with other connected nodes in the network. Their number can be very high depending on their application. Being small in terms of usability is a physical requirement. These nodes recognize each other by being randomly left to the physical environment to be observed. Nodes can cooperate and perform measurements in a wide area [3].

The energy constraint is one of the most significant difficulties of the sensor network systems, dispersed in a wide geographical area. For the stored energy to be used for a long time, protocols that optimize energy usage are required [4]. Due to battery life limitations, they are operated in "sleep" mode for low power consumption in the sensor nodes at times, not measurement. Thus, wireless sensor networks perform far beyond traditional sensor systems using large, expensive macro sensors, and required wiring to the user [5].

Because wireless sensors are powered by commercially available batteries, battery performance will directly affect the performance of the entire network. Batteries contain two electrodes, an anode (negative end) and a cathode (positive end). An electric current flows between the two electrodes, mainly due to the voltage difference between the anode and cathode. Voltage passes through a chemical called an electrolyte (which can be liquid or solid). A battery consists of plates made of reactive chemicals separated by barriers. All electrons are collected on one side and after a battery is polarized, it is negatively charged. Meanwhile, the other side becomes positively charged. Connecting a device to the terminals of the battery creates a current in which electrons flow from the device to the positive side. An electrochemical reaction takes place inside batteries to regenerate electrons. The effect is a chemical process that generates electrical energy, but as with many chemical reactions, the process is affected by temperature. When an increase in temperature occurs, the electrons become active. On the other hand, a decrease in temperature can hinder electron activities. If a device containing batteries is exposed to extreme temperatures for any period of time, there will be an adverse effect on the batteries. Also, a rapid temperature change can lead to condensation, posing a potential hazard to a battery and associated devices [6]. Especially the changes in air humidity can cause condensation, which can be detrimental to batteries [7]. 


\begin{tabular}{|c|c|c|}
\hline & $\begin{array}{l}\text { BŞEÜ Fen Bilimleri Dergisi } \\
8(1), 263-269,2021\end{array}$ & $\begin{array}{r}\text { BSEU Journal of Science } \\
\text { https://doi.org/10.35193/bseufbd } 880520\end{array}$ \\
\hline & & 2458-7575 (https://dergipark.org.tr/tr/pub/bseufbd) \\
\hline
\end{tabular}

In wireless sensor networks, the implementation of energy efficiency protocols will reduce energy consumption. Environmental factors are thought to impact battery consumption, as data measurement takes place under entirely natural conditions. In order to determine the battery consumption influenced by temperature and humidity in a greenhouse where an open-source wireless sensor system is installed, this study aims to determine the daily battery voltage change in temperature and humidity sensors that measured at different locations in the greenhouse, according to the temperature and relative humidity value. Temperature and relative humidity values in the greenhouse can take extreme values depending on the seasons and the agricultural activities applied. In the study, the effect of temperature and relative humidity changes on the battery voltage will be determined. In particular, it will be determined whether two environmental factors cause extreme drops in the battery voltage level. Because the wireless sensors can make accurate measurements within the battery voltage range specified in the datasheet.

\section{MATERIAL AND METHOD}

As the wireless sensor network system in greenhouse, Silicon Labs Si7021 humidity and temperature (\% $\mathrm{RH}$ and ${ }^{\circ} \mathrm{C}$ ) sensors are used. The sensors are mounted on the redesigned board using the Arduino Uno R3 board with the I2C interface. CRC compatible Nordic nRF24L01 + chips were used as radio for sending data to the collection and routing station. The system is primarily designed for low power consumption, not for data transmissions to long distances. Thus, the ArduinoUnoR3 design was simplified and a voltage divider was used on the circuit board to monitor the processor, radio, sensor and battery status. The nRF24L01 + regular radios used in data transmission are connected to the Atmega328P processor via SPI (Serial Hardware Interface). The sensors are powered by batteries only. Totally 18 Silicon Labs Si7021 sensor systems were used in the study. Silicon Labs Si7021 operating voltage is between 1.9 V-3.6 V [8]. In order to avoid any kind of effects on battery's chemical structured, an internal voltage calibration feature in the Si7021 sensor was used in the study. The greenhouse in which the study was conducted is $8 \mathrm{~m} * 20 \mathrm{~m}$ in size. The positions of the sensors placed inside and outside the greenhouse are given in Table 1. One corner of the greenhouse is the origin, the short side of the greenhouse is given as $\mathrm{X}$ and the long side as $\mathrm{Y}$.

Table 1. Locations of the sensors

\begin{tabular}{cccc}
\hline Sensor Number & $\begin{array}{c}\text { X } \\
\mathbf{m}\end{array}$ & $\begin{array}{c}\text { Y } \\
\mathbf{m}\end{array}$ & $\begin{array}{c}\text { Height } \\
\mathbf{m}\end{array}$ \\
\hline 304 & 8 & 0 & 1 \\
311 & 8 & 3.5 & 0.5 \\
314 & 8 & 12 & 2 \\
320 & 8 & 0 & 1 \\
325 & 0 & 10 & 0.5 \\
326 & 8 & 0 & 1 \\
327 & 8 & 10 & 0.5 \\
346 & 6 & 18 & 1.5 \\
363 & 8 & 0 & 1 \\
385 & 0 & 18 & 0.5 \\
$389^{*}$ & 0 & 18 & 0.5 \\
391 & 8 & 6.5 & 1.5 \\
$393 *$ & 0 & 18 & 0.5 \\
$394^{*}$ & 0 & 26 & 2 \\
$398^{*}$ & 0 & 18 & 1 \\
401 & 8 & 3.5 & 1.5 \\
405 & 8 & 4.5 & 0.5 \\
406 & 0 & 6 & 1.5 \\
\hline
\end{tabular}

The greenhouse wireless sensor system has relatively low power consumption, as it is already aimed to maintain the system for years without the need for battery replacements. For this reason, it has been tried to select appropriate materials with the lowest battery consumption. Temperature, relative humidity and sensor battery voltage measurements were carried out for twelve months between 2016-2017 in five minute intervals. The nRF24L01 + radio in data communication is encoded to send data in $2420 \mathrm{MHz}, 2440 \mathrm{MHz}, 2460 \mathrm{MHz}$ and 2480 MHz ISM bands.

For the analysis of the obtained data, a Python Script was used to get the sensors' information and formatting this accumulated data since the data file exceeds the Gigabyte size. Daily average temperature and 


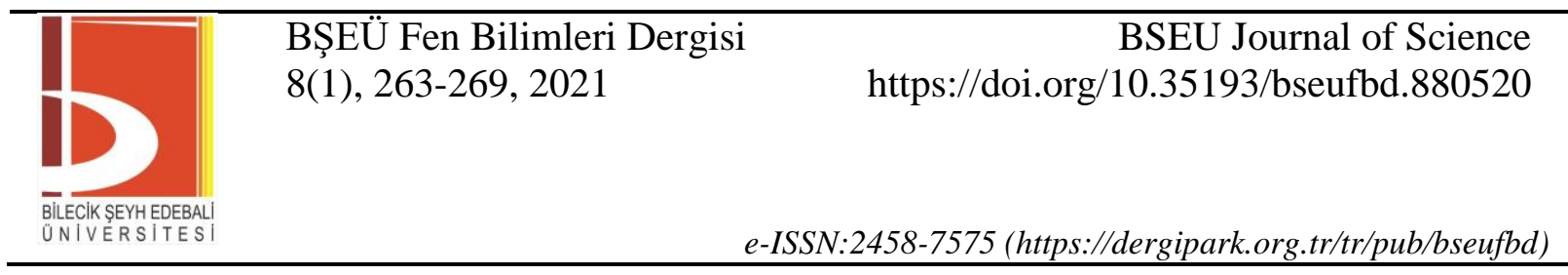

relative humidity values with daily maximum-minimum battery voltage were determined for each sensor. Regression and correlation analyzes were performed as a statistical evaluation process for the obtained results.Data were tested by using a two-way Analyses of Variance (ANOVA) (two factors; (i) temperature and (ii) relative humidity) with SPSS 15.0 statistical package for windows, SPSS Inc., Chicago.

\section{RESULTS}

The collected data are saved in a .txt file. The collected data are date, time, sensor number, sensor type, temperature, relative humidity, battery level, and the number of accumulated data as cycle (Table 2).

Table 2. Example of data file structure

\begin{tabular}{ccccccc}
\hline Date & Time & $\begin{array}{c}\text { Sensor } \\
\text { Number }\end{array}$ & $\begin{array}{c}\text { Sensor } \\
\text { Type }\end{array}$ & $\begin{array}{c}\text { Temperature, }{ }^{\circ} \mathbf{C} \\
(/ \mathbf{1 0 0})\end{array}$ & $\begin{array}{c}\text { Relative Humidity \% } \\
(/ \mathbf{1 0 0})\end{array}$ & $\begin{array}{c}\text { Battery Level, V } \\
(/ \mathbf{1 0 0 0})\end{array}$ \\
\hline 31.07 .2016 & $06: 42: 13$ & 314 & $\mathrm{R}$ & 1978 & 7264 & 991 \\
31.07 .2016 & $06: 42: 30$ & 398 & $\mathrm{R}$ & 2231 & 6507 & 2908 \\
31.07 .2016 & $06: 42: 51$ & 405 & $\mathrm{R}$ & 2243 & 6428 & 1102 \\
31.07 .2016 & $06: 43: 08$ & 401 & $\mathrm{R}$ & 2258 & 6588 & 1342 \\
31.07 .2016 & $06: 43: 11$ & 363 & $\mathrm{R}$ & 2260 & 6460 & 1016 \\
31.07 .2016 & $06: 43: 11$ & 393 & $\mathrm{R}$ & 2275 & 6276 & 944 \\
31.07 .2016 & $06: 43: 28$ & 325 & $\mathrm{R}$ & 2343 & 6263 & 994 \\
31.07 .2016 & $06: 43: 37$ & 394 & $\mathrm{R}$ & 2081 & 7303 & 924 \\
\hline
\end{tabular}

From the data in this file, the data of each sensor have been transferred in to individual files. The daily average temperature, relative humidity and battery level change values in the resulting files were calculated (Table $3)$. The values obtained were subjected to statistical analysis separately and together for each sensor.

Table 3. Daily battery voltage change, temperature and relative humidity

\begin{tabular}{ccc}
\hline $\begin{array}{c}\text { Daily Battery Level Change } \\
\mathbf{m V}\end{array}$ & $\begin{array}{c}\text { Daily Average Temperature } \\
{ }^{\circ} \mathbf{C}\end{array}$ & $\begin{array}{c}\text { Daily Average Humidity } \\
\%\end{array}$ \\
\hline 3 & 10.27 & 87.01 \\
3 & 6.70 & 82.29 \\
5 & 6.59 & 73.91 \\
9 & 7.39 & 69.80 \\
14 & 9.63 & 68.69 \\
11 & 6.66 & 67.70 \\
14 & 7.87 & 62.69 \\
13 & 7.30 & 61.77 \\
\hline
\end{tabular}

Boxplot graph of temperature and battery voltage level change of one randomly selected sensor was prepared to see the temperature and battery level change intervals (Figure 1a). As can be seen in Figure 1a, temperature values varied in a wide range between $2-38^{\circ} \mathrm{C}$ against the change of daily battery level change in the range of 1-20 mV. In this sensor, extreme values, such as >20 mV were obtained in battery level change. Since these values are out of general, they are not evaluated. When the daily average temperature-daily battery level change values of all sensors were evaluated together, it was observed that the temperature changes in a wide range at the same battery level value. A boxplot graph of the humidity and battery level change of one randomly selected sensor was prepared to see the relative humidity and battery level change intervals (Figure 1b). As can be seen in Figure $1 b$, the daily battery level change ranged from $1-19 \mathrm{mV}$, humidity values ranged from $25-90 \%$. Relative humidity values corresponding to the same battery level change are tended to approach an average value, unlike temperature. As can be seen in Figure 1b, the daily battery level change ranged from 1-19 mV, relative humidity values ranged from $25-90 \%$. Relative humidity values corresponding to the same battery level change are tended to approach an average value, unlike temperature. 


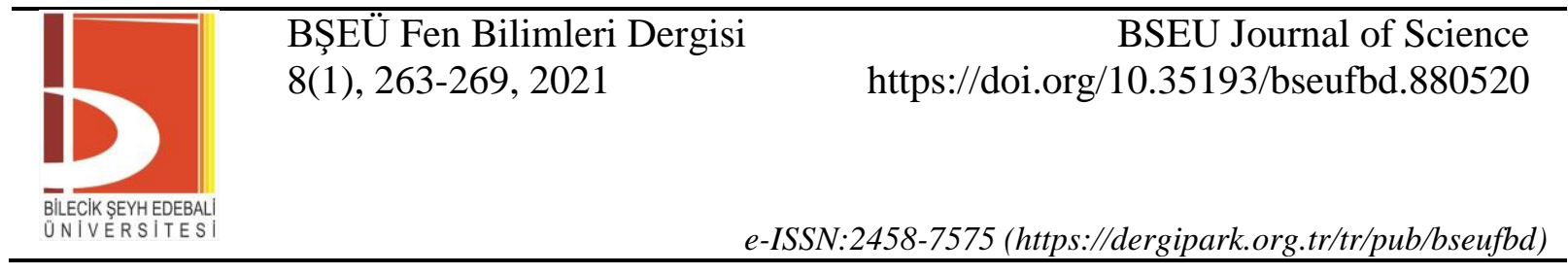
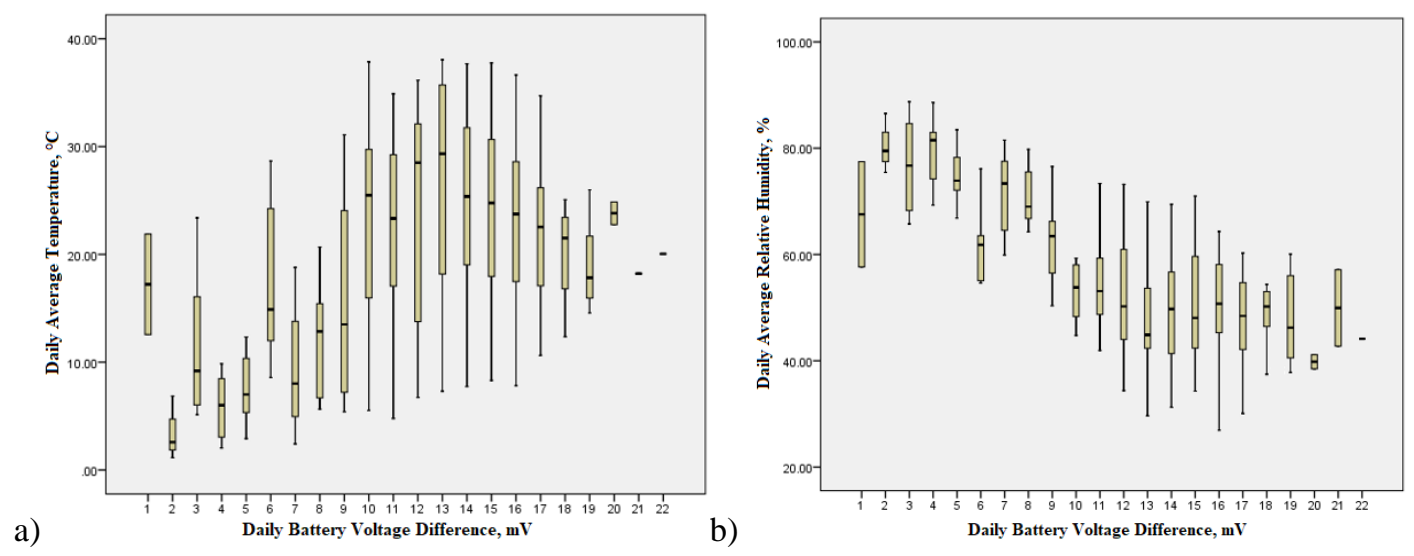

Figure 1. Daily Average temperature (a) and Humidity (b) with daily battery voltage level difference

Correlation analysis was made between daily battery voltage differences, average daily temperature and relative humidity values. Table 4 shows the correlation coefficient between daily battery voltage differences and the other two parameters. According to the result of the correlation analysis, there is a relationship at significance level of $p \leq 0.01$ between the greenhouse temperature and the difference in the daily battery voltage level in 10 sensors ( 5 of them are positive, 5 of them are negative), other one has a positive relationship at the significance level of $\mathrm{p} \leq 0.05$, and the others do not have. There is a relationship between daily battery voltage level difference and daily average relative humidity at $\mathrm{p} \leq 0.01$ significant level at 14 sensors (positive relationship in 3 sensors and negative in 11 sensors), while the other four sensors do not.

Table 4. Correlation Coefficients between Daily Battery Voltage Differences, Average Daily Temperature and Relative Humidity

\begin{tabular}{|c|c|c|}
\hline $\begin{array}{c}\text { Sensor } \\
\text { Number }\end{array}$ & Temperature & $\begin{array}{c}\text { Relative } \\
\text { Humidity }\end{array}$ \\
\hline 304 & $-.200 * *$ & -.076 \\
\hline 311 & -.067 & -.030 \\
\hline 314 & $.346^{* *}$ & $-.443 * *$ \\
\hline 320 & -.019 & $-.482 * *$ \\
\hline 325 & $.480 * *$ & $-.612 * *$ \\
\hline 326 & .097 & $-.265^{* *}$ \\
\hline 327 & $.449 * *$ & $-.653 * *$ \\
\hline 346 & .099 & $-.176 * *$ \\
\hline 363 & $.119 *$ & $-.463 * *$ \\
\hline 385 & 0.14 & $-.154 * *$ \\
\hline 389 & .119 & .131 \\
\hline 391 & .102 & $-.242 * *$ \\
\hline 393 & $-.153 * *$ & $.137 * *$ \\
\hline 394 & $.493 * *$ & $-.526 * *$ \\
\hline 398 & $-.195 * *$ & $.209 * *$ \\
\hline 401 & $.460 * *$ & $-.632 * *$ \\
\hline 405 & $-.267 * *$ & .004 \\
\hline 406 & $-.197 * *$ & $.136 * *$ \\
\hline
\end{tabular}

Regression and ANOVA analysis was done separately and together between daily battery voltage differences and average daily temperature and relative humidity values. The regression coefficients obtained as a result of the regression analysis are given in Table 5. In addition, ANOVA significance level values ( $\mathrm{p} \leq 0.01$ and $\mathrm{p} \leq 0.05$ ) obtained as a result of ANOVA analysis are shown on the regression coefficients. 


\begin{tabular}{|c|c|c|}
\hline & $\begin{array}{l}\text { BŞEÜ Fen Bilimleri Dergisi } \\
8(1), 263-269,2021\end{array}$ & $\begin{array}{r}\text { BSEU Journal of Science } \\
\text { https://doi.org/10.35193/bseufbd.880520 }\end{array}$ \\
\hline $\begin{array}{l}\text { BiLCECKSYYH EDEBALI } \\
\text { ONIVERSITESI }\end{array}$ & & 2458-7575 (https://dergipark.org.tr/tr/pub/bseufbd) \\
\hline
\end{tabular}

According to the regression analysis results, the regression coefficient was obtained very low for all sensors. According to the results of ANOVA analysis, it was seen that the relationship between daily temperature and relative humidity values and the change of battery voltage is statistically significant at $p \leq 0.01$ level in most sensors. When temperature and relative humidity were evaluated together, it was seen that the relationship was statistically significant at $\mathrm{p} \leq 0.01$ level in all sensors.

Table 5. Regression analysis of temperature, relative humidity and temperature combined with relative humidity

\begin{tabular}{|c|c|c|c|}
\hline Sensor Number & Temperature & Relative Humidity & $\begin{array}{c}\text { Temperature + Relative } \\
\text { Humidity } \\
\end{array}$ \\
\hline & $\mathbf{r}^{2}$ & $\mathbf{r}^{2}$ & $\mathbf{r}^{2}$ \\
\hline 304 & $0.040 * *$ & 0.006 & $0.100 * *$ \\
\hline 311 & 0.040 & $0.010 * *$ & $0.025 * *$ \\
\hline 314 & $0.120 * *$ & $0.196 * *$ & $0.197 * *$ \\
\hline 320 & 0 & $0.232 * *$ & $0.311 * *$ \\
\hline 325 & $0.230 * *$ & $0.412 * *$ & $0.430 * *$ \\
\hline 326 & 0.009 & $0.070 * *$ & $0.093 * *$ \\
\hline 327 & $0.201 * *$ & $0.427 * *$ & $0.442 * *$ \\
\hline 346 & 0.010 & $0.031 * *$ & $0.035 * *$ \\
\hline 363 & $0.014 *$ & $0.214 * *$ & $0.278 * *$ \\
\hline 385 & 0 & $0.024 * *$ & $0.059 * *$ \\
\hline 389 & 0.014 & 0.017 & $0.118 * *$ \\
\hline 391 & 0.010 & $0.059 * *$ & $0.090 * *$ \\
\hline 393 & $0.024 * *$ & $0.019 * *$ & $0.025 * *$ \\
\hline 394 & $0.243 * *$ & $0.277 * *$ & $0.304 * *$ \\
\hline 398 & $0.038 * *$ & $0.044 * *$ & $0.046 * *$ \\
\hline 401 & 0.016 & $0.035 * *$ & $0.037 * *$ \\
\hline 405 & $0.071 * *$ & 0 & $0.214 * *$ \\
\hline 406 & $0.039 * *$ & $0.019 * *$ & $0.040 * *$ \\
\hline
\end{tabular}

\section{DISCUSSION AND CONCLUSION}

In the study, the same feature material and battery were used in all sensors. However, in the sensors measuring at different points, the batteries' reactions to the temperature and relative humidity were not in the same direction. When the daily average temperature-daily battery level change values of all sensors were evaluated together, it was observed that the temperature changes in a wide range at the same battery level value.

As one of the environmental factors, the effect of temperature on battery discharge characteristics in wireless sensor networks was investigated in [9]. It was determined that the batteries used in the wireless sensor networks, continuous exposure to high temperature cause increased charge loss, shortens the battery life, and exposure to low temperature decreases the battery capacity due to the increase of the battery's internal resistance.

In another study, it was stated that the thermal effect in wireless sensor network systems could accelerate the rate of chemical reactions in the battery, which can provide higher adequate capacity at higher temperatures. They stated that the model they developed could be used to estimate battery behavior and battery life at different operating temperatures [10]. On the other hand, some researchers gave the results of the model they prepared to determine the relationship between temperature and battery capacity drop. They noticed that the model they used in their studies was verified in systems with high energy consumption, high discharge current (> $100 \mathrm{~mA})$, but in systems, such as WSN with low current draw, no accurate results were obtained [11].

Relative humidity values corresponding to the same battery voltage change are tended to approach an average value, unlike temperature. There are positive and negative relationships in equal number of sensors for significance level $\mathrm{p} \leq 0.01$, between the average daily temperature value and the average battery voltage level change. There is a negative relationship in most sensors for same significance level between the average daily relative humidity value and the average battery voltage level change.

When collected results were evaluated together, it was observed that the changes in daily battery levels of 18 sensors with the same features did not have similarity concerning temperature and relative humidity values. 
Each sensor system was evaluated according to the temperature and relative humidity at its location. Similarities were not observed in the results obtained from sensors that were close to each other. Therefore, the possible influence of the location on the heterogeneity of the results was neglected. As seen in Figure 1, the daily battery voltage difference range was between $0-22 \mathrm{mV}$ in other sensors also. According to the operating voltage of the Si7021 sensor (between1.9V-3.6V), the amount of daily voltage variation depending on the average daily temperature and relative humidity conditions were remaining at a very low level during 12 months.

In all sensor values that were statistically significant between battery level changes and temperature and humidity values, the $\mathrm{r}^{2}$ value was lower than 0.5 . Accordingly, it is not possible to estimate the battery level change using only temperature and humidity values. A regression equation cannot be created using these parameters. In another study, it was mentioned that the batteries used in wireless sensor systems were affected by extreme pressure, temperature and humidity conditions. It is concluded that temperature is more pronounced among these climate parameters [12].

Systems that are planned to include only the elements suitable for the purpose, as in our study, can serve more than one year without requiring battery replacement. The effect of temperature and humidity changes that will occur in extreme conditions on batteries used in wireless sensor systems has not been statistically proven yet. The use of battery-powered, wireless sensor systems in greenhouse-like environments with high daily, seasonal temperature and humidity changes will not be a problem in temperature and humidity. Possible effects of other environmental factors on daily change in battery level are topics that can be explored in future studies.

\section{TEŞEKKÜR}

This study was carried out within the scope of project numbered BAP OUAP (Z) -2015/10, supported by the Scientific Research Projects Unit of Bursa Uludağ University. We thank Bursa Uludağ University Scientific Research Projects Unit for its support.

\section{REFERENCES}

[1] Kalaycı, T. E. (2009). Kablosuz Sensör Ağlar ve Uygulamaları, Akademik Bilişim’09 - XI. Akademik Bilişim Konferansı Bildirileri, 11-13 Şubat 2009 Harran Üniversitesi, Şanlıurfa.

[2] Tekin, Ç., Demirel, A.B. \& Örün, Ç. (2011).Tarımda Kablosuz Ağlar, Akademik Bilişsim 2011, İnönü Üniversitesi, Malatya.

[3] Sarpay, A. (2016). İnternet Kullanımının Çevresel Etkileri, Yüksek Lisans Tezi, Ankara Üniversitesi, Sosyal Bilimler Enstitüsü, Ankara.

[4] Suri, A., Iyengar, S. S. \& Cho, E. (2006). Ecoinformatics using wireless sensor networks: An overview, Ecological Informatics, 1, 287-293.

[5] Odabaş1, S. \& Tozan, Ş. D. (2009). Kablosuz Sensör Ağlar ve Kablosuz Sensör Ağlarda Enerji Tüketimi, Elektrik-Elektronik-Bilgisayar ve BiyomedikalMühendisliği 13. Ulusal Kongresi, Ankara.

[6] Guo, W., Healy, W. M. \& Zhou, M. (2013). Experimental study of the thermal impacts on wireless sensor batteries, 2013 10th IEEE International Conference on Networking, Sensing and Control (ICNSC), 430-435, doi: 10.1109/ICNSC.2013.6548777.

[7] Anonymous (2021). https://www.panasonic-batteries.com/en/cold-weather-batteries, (Date of access: 10.05.2021).

[8] Anonymous (2021). Silicon Lab Si7021 datasheet, https://www.silabs.com/documents/public/datasheets/Si7021-A20.pdf, (Date of access: 13.05.2021).

[9] Park, C., Lahiri, K. \& Raghunathan, A. (2005). Battery discharge characteristics of wireless sensor nodes: an experimental analysis. 2005 Second Annual IEEE Communications Society Conference on Sensor and Ad Hoc Communications and Networks, 2005. IEEE SECON 2005., Santa Clara, CA, USA.

[10] Rodrigues, L. M., Montez, C., Moraes, R., Portugal, P. \& Vasques, F. (2017). A temperature-dependent battery model for wireless sensor networks, Sensors, 17(2), 422.

[11] Erdinç, O., Vural, B. \& Uzunoğlu, M. (2009). A dynamic lithium-ion battery model considering the effects of temperature and capacity fading, International Conference on Clean Electrical Power, Capri, Italy, 383386.

[12] Rodrigues, L., Leao, E., Montez, C., Moraes, R., Portugal, P. \& Vasques, F. (2018). An Advanced Battery Model for WSN Simulation in Environments with Temperature Variations. IEEE Sensors Journal, 18(19), 8179-8191. 